\title{
O ano da vida e da morte do estoico Ricardo Reis
}

\author{
Pedro Nunes de Castro* \\ Rosane Maria Cardoso ${ }^{\dagger}$
}

\section{Introdução $^{1}$}

Este artigo postula a intersecção profícua das áreas da literatura e da filosofia, pois ambas mergulham em temáticas pertinentes à condição humana, tais como o mote socrático do autoconhecimento. Esse tema universal, através da apropriação de Saramago, suscita o viés ético, porquanto se o autor português escreveu no intuito de desvelar quem é o ser humano, também o fez para transformá-lo. Por isso, tencionamos cotejar $O$ ano da morte de Ricardo Reis (SARAMAgo, 2011) com o âmbito ético do estoicismo, cujo mentor foi Zenão de Cítio (34o a.c.- 264 a.c.). ${ }^{2}$ Frisamos que esta pesquisa não colide com as que esmiuçaram a absorção da poesia de Fernando Pessoa e a conexão dela com a temática da nação portuguesa. ${ }^{3} \mathrm{O}$ que firmamos é que as teorias estoicas permeiam os conteúdos supramencionados.

Fixando-nos na narrativa referida, ressaltamos que sua análise exige uma acuidade particular no que tange às semelhanças e diferenças entre o heterônimo Ricardo Reis, criação de Fernando Pessoa, e o protagonista, recriação do prêmio Nobel de Literatura. O primeiro se declara estoico: "Negue-me tudo a sorte, menos

Pós-doutorando em Letras na Universidade de Santa Cruz do Sul (UNISC), Santa Cruz do Sul, RS, Brasil. E-mail: pedro.nunesdecastro@gmail.com

$\dagger$ Doutora em Teoria da Literatura e professora da Universidade do Vale do Taquari (Univates) e da Universidade de Santa Cruz do Sul (UNISC), Santa Cruz do Sul, RS, Brasil. E-mail: rosanemc@unisc.br

1 Esta pesquisa originou-se da tese de doutorado em Literatura de Pedro Nunes de Castro, defendida na Universidade Federal de Santa Catarina (UFSC) em 2015, sob orientação de João Eduardo P. Basto Lupi.

2 O estoicismo ficou conhecido como filosofia do pórtico porque o fundador Zenão reunia-se com os discípulos ao abrigo de um pórtico. Esta corrente filosófica é dividida em três grandes fases: antigo, médio e romano. Igualmente, a exposição das teorias dá-se sob três esferas: a lógica, a física e a ética.

3 Inclusive Saramago declarou que, ao escrever este livro, inspirou-se em Portugal, sugerindo como um eventual subtítulo: "Contribuição para o diagnóstico da doença portuguesa" (SARAMAGO, 2010, p. 282). É possível aventar que as atitudes de Ricardo Reis refletem as da nação lusa, uma vez que ele demonstra insegurança quanto à própria identidade e alienação em relação à conjuntura político-social. 
vê-la, / Que eu, 'stoico sem dureza, / Na sentença gravada do Destino / Quero gozar as letras" (PESSOA, 2007, p. 90-91). O segundo, por sua vez, conserva o teor das odes do heterônimo de outrora, conquanto ao aterrar na chuvosa Lisboa, no final de 1935, apresente peculiaridades. Preconizamos que a validade da crítica em tela provém da compreensão de que, não obstante as transformações do heterônimo para o protagonista, este mantém o estoicismo daquele.

Adotaremos, como referenciais metodológicos, os conceitos de dialogismo e intertextualidade, de acordo com o que Kristeva elucida:

Em Bakhtine, [...] os dois eixos, por ele denominados diálogo e ambivalência, respectivamente, não estão claramente distintos. Mas esta falta de rigor é antes uma descoberta que Bakhtine é o primeiro a introduzir na teoria literária: todo texto se constrói como mosaico de citações, todo texto é absorção e transformação de um outro texto. Em lugar da noção de intersubjetividade, instala-se a de intertextualidade e a linguagem poética lê-se pelo menos como dupla (KRISTEVA, 1974, p. 64, grifos da autora).

A intertextualidade é qualificada como uma característica inerente ao texto literário e a relação dialógica, por sua vez, embasa-se em componentes intertextuais. Mikhail Bakhtin caracteriza o dialogismo:

As relações dialógicas são possíveis não apenas entre enunciações integrais (relativamente), mas o enfoque dialógico é possível a qualquer parte significante do enunciado, inclusive a uma palavra isolada caso esta não seja interpretada como palavra impessoal da língua, mas como signo da posição interpretativa de um outro, como representante do enunciado de um outro, ou seja, se ouvimos nela a voz do outro. Por isto, as relações dialógicas podem penetrar no âmago do enunciado, inclusive no íntimo de uma palavra isolada se nela se chocam dialogicamente duas vozes (BАKнтіN, 1981, p. 159-160).

Sublinhamos o fragmento de que ouvimos, em um determinado enunciado, $a$ voz do outro. Marinho realça idêntica perspectiva: "A ideia de um discurso que é o tempo todo atravessado pelo alheio, que traz no seu interior o outro é um dos principais pontos do pensamento de Mikhail Bakhtin e o fundamento de sua concepção dialógica da linguagem" (MArinho, 1997, p. 249). Portanto, o texto que se relaciona dialogicamente com outro é, por sua vez, moldado por ele. O discurso que está no horizonte de refutação integra, de certa forma, o discurso contestatório:

Apesar das diferenças substanciais, todos esses fenômenos [estilização, paródia, skaz, diálogo] têm um traço em comum: aqui a palavra tem duplo sentido, voltando-se para o objeto do discurso enquanto palavra comum e para um outro discurso, para o discurso de um outro. Se desconhecemos a existência desse segundo contexto do discurso do outro e começarmos 
a interpretar a estilização ou a paródia como interpretamos o discurso comum voltado exclusivamente para o seu objeto, não entenderemos verdadeiramente esses fenômenos: a estilização será interpretada como estilo, a paródia, simplesmente como obra má (BAKHTin, 1981, p. 161, grifos do autor).

O pensador russo frisa que perscrutar o texto literário e distinguir elementos subjacentes que o compõem reverte em uma maior inteligibilidade da obra. Inferimos, pois, a legitimidade desta modalidade de crítica, visto que dela deriva a revelação de componentes textuais incógnitos.

Para alcançarmos o objetivo de trazer o discurso estoico ao primeiro plano da narrativa saramaguiana, cotejaremos duas temáticas: a pertinência da sabedoria e a crença na existência do destino. ${ }^{4}$ Esses conteúdos bifurcam-se em duas atitudes basilares: a mera contemplação ou a ação.

\section{Ricardo Reis e a sabedoria estoica}

O âmbito ético do estoicismo aborda uma temática universal, visto que se propõe a delinear diretrizes para que o ser humano obtenha a eudaimonia, isto é, a felicidade. O pórtico argumenta que, em última instância, a felicidade imbrica-se à sabedoria e à virtude, portanto, apenas o sábio é um ser virtuoso e, por consequência, feliz (SCHOFIELD, 2006).

Na perspectiva do heterônimo Ricardo Reis, há um verso célebre em que se determina qual é a atitude do sábio. É o primeiro de um poema que condensa seus princípios recorrentes, tais como a valorização do tempo presente em face da efemeridade da vida. ${ }^{5}$ É um verso cuja autoria poderia inclusive ser atribuída a algum filósofo estoico, dada a semelhança com duas sentenças de um notável nome da fase romana:

Sábio é o que se contenta com o espectáculo do mundo (PessoA, 2007, p. 36).

Só o sábio se contenta com o que tem, todos os insensatos sofrem de descontentamento consigo mesmos (SÊNECA, 2004, p. 28).

4 Consideramos que existem outros conteúdos substanciais que se interseccionam entre a narrativa e o pórtico, tais como a atitude diante das emoções e a valorização da razão, mas que serão explanados em outro artigo.

5 "Para quem tudo é novo / E imarcescível sempre" (PESSOA, 2007, p. 36). São pontos também valorizados pelo pórtico: "La teoría estoica estándar, derivada presumiblemente de Crisipo, era que sólo el presente es completamente real” (RIsT, 1995, p. 286). 
Entre nós [estoicos] e eles [epicuristas] existe um ponto comum: o sábio contenta-se consigo próprio (SÊNECA, 2004, p. 22). ${ }^{6}$

Ressaltamos a equivalência das assertivas: tanto a de Ricardo Reis quanto as de Sêneca enaltecem a sabedoria e condicionam sua obtenção ao contentamento. E o embasamento da diretriz ética acima está alicerçado no plano da física estoica.

Zenão de Cítio e seguidores explanaram que o universo é um todo orgânico e harmônico, sob a égide de uma força denominada logos. Uma das suas características, que é intrínseca à natureza, é a racionalidade. Para obtermos a desejada paz de espírito é necessário estar em harmonia com o logos, por isto, o summum bonum é viver de acordo com a natureza, isto é, de acordo com a razão (REALE, 1994). O pórtico preconiza que esta força universal, imanente a todas as coisas, ordena tudo de forma necessária e perfeita. $\mathrm{O}$ entendimento de que todos os eventos são necessários, acarreta a percepção de que tudo o que ocorre é absolutamente inevitável. E se o status quo dos acontecimentos detém os adjetivos de, além de necessário, perfeito, assevera-se que o mal não existe. A falsa impressão de sua existência sobrevém ao analisar os eventos de forma fragmentada, porquanto um exame abrangente e global constatará que cada circunstância contribui para o bem da totalidade (Duнот, 2006). Sendo assim, lamentar determinadas ocorrências decorre de ignorância, já que elas estão coadjuvando para o bem do todo. Portanto, o sábio não lamuria, ele se contenta. ${ }^{7}$ Não obstante as já enunciadas transformações do heterônimo para o protagonista, este mantém o verso transcrito como filosofia de vida: "Ricardo Reis é um espectador do espectáculo do mundo, sábio se isso for sabedoria, alheio e indiferente por educação e atitude" (SARAMAGO, 2011, p. 98, grifo nosso). ${ }^{8}$ O contexto impele-nos a inferir que a partícula condicional "se" sinaliza uma primeira divergência. Através dela, o narrador põe em dúvida a máxima do heterônimo assumida pelo protagonista, de que contentar-se diante do espetáculo do mundo seja uma decisão sábia. E a sequência do excerto evidencia que tal bordão decorre da filiação estoica de Ricardo Reis: "afinal é tão fácil compreender os antigos gregos e romanos quando acreditavam que se moviam entre deuses" (p. 98, grifo nosso). A referência aos gregos e aos romanos é uma alusão velada ao pórtico, porquanto salienta seu nascimento e difusão. Portanto, as objeções expostas na narrativa ocorrem ao lema de Ricardo Reis, prisma já consolidado pela fortuna crítica. Conforme Silva, $O$ ano da morte "constrói-se todo ele, como interpelação da máxima deste heterônimo de Pessoa" (SILVA, 2005, p. 31). O que aditamos de singular é que as dissensões a este verso são, a uma só vez, dissensões aos preceitos estoicos. Esta é a relação dialógica e intertextual elucidada

\footnotetext{
Embora Sêneca realce um ponto em comum com os epicuristas, cabe a ressalva de que eram duas escolas rivais e que detinham divergentes concepções de mundo, conforme será indicado no decorrer do artigo.

7 O enredo de "Cândido ou o optimismo" ironiza tal compreensão de que vivemos no "melhor dos mundos possíveis" (Voltaire, 2005, p. 220).

8 As próximas citações de $O$ ano da morte de Ricardo Reis (2011) serão da mesma edição, sendo identificadas doravante apenas pelo número da página.
} 
por Kristeva que, ao deslindar as teorias de Bakhtin, reitera que o pensador russo: "tem em vista a escritura como leitura do corpus literário anterior, o texto como absorção de, e réplica a um outro texto" (KRIsteva, 1974, p. 67). Para ilustrar recorremos a uma metáfora cujos textos são constituídos por múltiplos estratos articulados. A relação dialógica estabelecida com um dos estratos efetiva-se com os demais, que a ele estão imbricados. No romance de Saramago, entendemos que as objeções à poesia de Ricardo Reis remetem aos preceitos estoicos.

Com a finalidade de prosseguir evidenciando a vitalidade dos preceitos estoicos em $O$ ano da morte, trasladamos o excerto em que o narrador se refere às estatísticas de óbitos em Portugal: "setecentos trinta e quatro eram crianças com menos de cinco anos de idade, quando é assim em cidades capitais, trinta por cento, [...] porém fica-nos a consolação de serem portugueses a maior parte dos anjinhos do céu" (p. 103). A discordância manifesta-se ao assentir ironicamente que o mal não existe, sendo que até a morte das crianças traria benefício, qual seja, o fato de serem portugueses os anjinhos do céu. Tal notícia é precedida pelo desígnio: "não é muito nem pouco, é o que tem de ser" (p. 103, grifo nosso). O bordão grifado denota uma acepção fatalista dos acontecimentos, porquanto a ele subjaz a pressuposição de que as circunstâncias atrozes supramencionadas foram inevitáveis. É um conteúdo que se articula com o que será aprofundado no próximo item, a crença na existência do destino.

Entretanto, antes de progredirmos na explanação, acentuamos um dado referente ao estoicismo. O pórtico é uma corrente filosófica que teve repercussão em toda a história da filosofia. Há mais de vinte séculos ele é estudado, sendo que sobre suas teorias, mormente na esfera da ética, não há uma interpretação unânime. Transcrevemos a síntese de duas vertentes:

Ele [o sábio] não participa das vicissitudes do mundo, não se apaixona por ele, é, tal como Zeus, o espectador que vê o seu inevitável produzirse (SEVERINO, 1984, p. 173).

O estoico não pode, se quiser ser virtuoso, cultivar o isolamento, mas deve decidir-se pela vida ativa (HIRSCHBERgER, 1965, p. 276).

São duas interpretações contrastantes dos mesmos preceitos. Da primeira grifamos dois tópicos pertinentes: a divindade é impassível, apenas assiste aos eventos, por serem inevitáveis; em segundo lugar, esta divindade é um modelo a ser imitado por aqueles que almejam serem felizes. Sêneca ratifica: "Aquilo que a filosofia me prometeu foi tornar-me igual à divindade. Foi esse o convite que recebi. Por isso vim. Respeite-se, portanto, a palavra dada" (SÊNECA, 2004, p. 165). Destacamos esse viés que prescreve a contemplação, por ser o que predomina na narrativa analisada. No entanto, não negligenciamos a existência da segunda vertente que apregoa a vida ativa e não a contemplativa como conditio sine qua non para 
que o ser humano seja sábio, virtuoso e feliz. Esse é um contexto em que o dialogismo ocorre em uma só palavra, segundo a teoria de Bakhtin, pois em "estoicismo" habitam significados diversos e contrastantes. ${ }^{9}$ Inclusive o filósofo Epicteto (55 d.c.-135 d.c.) admitiu a polissemia: "Com efeito, parte-se desses princípios sobre os quais todos estão de acordo e chega-se a controvérsias porque não se os aplica corretamente" (Ерістето apud Duнот, 2006, p. 137). Aderindo à concepção dialógica da linguagem, depreendemos que não há uma aplicação incorreta dos preceitos, mas apenas diversidades hermenêuticas.

Prosseguimos realçando o diálogo da narrativa com o pórtico no que tange à já anunciada temática do destino.

\section{Destino: o que tem de ser, tem de ser e tem muita força}

Destino, o que é? Será ele uma carta fechada à espera de que o destinatário a leia? Será ele o guia dos obedientes e o algoz dos insurretos? Ou seria o avaro administrador de nossa liberdade? Iniciamos o tópico com perguntas por ser uma temática filosófica por excelência, que instiga, sobretudo, questionamentos. Supondo a sua existência, o metafísico destino é o que mais poder possui sobre nós e do qual menos conhecimento dispomos.

$\mathrm{Na}$ acepção estoica, o sábio concebe a existência do destino vinculada à respectiva primazia sobre todos acontecimentos, dos extraordinários aos mais triviais. Cleantes (33o a.c.-23o a.c.), discípulo de Zenão de Cítio, compôs um hino proferindo o seu venturoso propósito: "Guia-me, Ó Zeus, e tu, Destino, ao termo, Qualquer que este seja, que te aprouve atribuir-me. Seguirei imediatamente, porque se me demoro, Por ser vil, do mesmo modo deverei alcançar" (CleAntes apud REALE, 1994, p. 328). O pensador apregoa que resistir ao fatum é uma atitude que deve ser repudiada, e em última instância é falha, visto que o desfecho é irrevogável. Para elucidar esta compreensão, forjou-se a analogia, cuja autoria é atribuída a Hipólito, de que o homem é como "um cão amarrado atrás de uma carroça: podemos seguir de bom grado ou ser puxados com força, mas seguiremos, de todo modo, o movimento" (SEDLEY, 2013, p. 105). O destino é a carroça que nos conduzirá se o seguirmos, ou arrastará, se formos desobedientes. ${ }^{10} \mathrm{O}$ entendimento é de que inúmeros acontecimentos estão no mesmo grau de irrevogabilidade da morte (Rist, 1995). ${ }^{11}$ Os detratores do pórtico, epicuristas por exemplo, valeram-se desse juízo

\footnotetext{
Fragmento citado na introdução deste trabalho: "Por isto, as relações dialógicas podem penetrar no âmago do enunciado, inclusive no íntimo de uma palavra isolada se nela se chocam dialogicamente duas vozes" (BAKHTin, 1981, p. 159-160).

1o Em harmonia com esta imagem, Sêneca elaborou a máxima: "Ao que se lhe submete, o destino o conduz; quem não se sujeita, é arrastado" (SÊNECA apud UllmanN, 1996, p. 88).

11 Antecipando-nos, demonstramos a conexão estabelecida entre destino e morte no romance de Saramago. Um homem morre na viagem que fazia a Fátima, e alguém comenta: "devia ter ficado em casa, mas ateimou, disse que se enforcava na trave da cozinha se o deixássemos, assim veio morrer longe, ninguém foge ao seu destino" (p. 346); "ao seu destino ninguém escapa, ninguém
} 
para criticá-lo, pois os estoicos não se indagavam sobre a contradição entre o poder atribuído ao destino e a existência da liberdade. Há uma distinção teórica bem demarcada entre ambas doutrinas, pois Epicuro inspirava-se nos atomistas e preconizava a prevalência do acaso em detrimento da necessidade. ${ }^{12}$ Do lado estoico, Crísipo (280 a.C.-208 a.C.) enunciou que há uma fissura entre duas realidades: a interior, onde a liberdade prevaleceria; e a exterior, cujo domínio estaria a cargo do destino e por isso extrapolaria à regência humana. Este raciocínio não deixou de ser objeto de contradita, porquanto o concerto entre destino e liberdade como realidades compatíveis inscreve-se no rol dos paradoxos estoicos. Não aprofundaremos tal contenda filosófica, limitar-nos-emos em esmiuçar o que a narrativa realça, qual seja, as consequências possíveis advindas da filiação a determinadas linhas de pensamento.

Para isto, expomos dois excertos, de $O$ ano da morte e do filósofo Sêneca:

Acima dos deuses está o destino, $\mathrm{O}$ destino é a ordem suprema, a que os próprios deuses aspiram, E os homens, que papel vem a ser o dos homens, Perturbar a ordem, corrigir o destino, Para melhor, Para melhor ou para pior, tanto faz, o que é preciso é impedir que o destino seja destino (p. 372).

Que coisa é própria do homem bom? Render-se ao fado, por ser grande consolo ser arrebatado com o universo. Que razão teve para mandar-nos viver e morrer assim? A mesma necessidade obrigou aos deuses, porque um irrevogável curso leva com igualdade as coisas humanas e as divinas (SÊNECA, 1952, p. 35, tradução nossa).

Esmiuçando a relação dialógica instaurada no romance, através da deliberação entre Ricardo Reis e Fernando Pessoa, com o entendimento de Sêneca, salientamos convergências e divergências. Ambos consentem que o destino sobrepõe-se aos deuses. Para Sêneca, "a mesma necessidade obrigou aos deuses" e, para Ricardo Reis, "Acima dos deuses está o destino". Porém, enquanto Sêneca apregoa que é próprio do homem bom "render-se ao fado", Fernando Pessoa preconiza que o papel dos homens é "corrigir o destino". Ou seja, pelo excerto acima, notamos a existência do que Bakhtin denominou como polifonia, uma vez que ecoam vozes divergentes sobre uma mesma temática. A adesão de Ricardo Reis, por sua vez, é sintetizada na sentença do título deste tópico: "O que tem de ser, tem de ser e tem muita força" (p. 228). O protagonista revela sob esse prisma, identificação com o heterônimo, que explicitara os seus princípios norteadores. "Por mim, se em mim

fica para semente, esta é uma grande verdade" (p. 262). O narrador propõe que se imagine como reagiriam as pessoas se tomassem conhecimento da sua morte pelo jornal: "destino marcado e a cumprir, dia, hora e lugar, o nome por inteiro, que fariam eles sabendo que os iam matar” (p. 55).

12 Recenseando as disparidades entre estoicos e epicuristas, acentuamos que os primeiros, conforme já foi exposto, sustentavam que a tendência natural do ser humano era viver de acordo com a razão, o logos. Epicuro, por sua vez, apregoava que a tendência inata era a busca do prazer. Nas odes do heterônimo Ricardo Reis, notamos matizes de ambas doutrinas, a racionalidade e a exatidão, bem como o Carpe diem de inspiração epicurista, similar a Horácio (PAIs, 2012). 
posso falar, quero ser ao mesmo tempo epicurista e estoico, certo que estou da inutilidade de toda ação num mundo em que a ação está em erro" (PEsSOA, 1998, p. 114, grifo nosso). Neste fragmento, há uma associação intrínseca entre o fato de ser estoico e a certeza da inutilidade de toda ação. Desenvolveremos essa vertente interpretativa herdada do poeta, criação de Fernando Pessoa, pelo protagonista, "recriação" de Saramago.

Efetiva-se uma relação de causa e efeito entre a adoção do pórtico como filosofia de vida e o comportamento contemplativo ou inativo. Eis uma passagem esclarecedora: "talvez isto é que seja o destino, sabermos o que vai acontecer, sabermos que não há nada que o possa evitar, e ficarmos quietos, olhando, como puros observadores do espectáculo do mundo" (p. 453). A crença na existência do destino está respaldando e promovendo a atitude de mero espectador. O subsequente extrato solidifica esse raciocínio: "encontrar ou não encontrar Marcenda parecialhe agora de mínima importância, estas coisas o melhor é entregá-las ao destino, queira ele que nos encontremos e assim há-de acontecer" (p. 349-350). Ou seja, ele se abstém de agir em nome de uma entidade estranha, o destino, que agirá por ele. O protagonista abona o que se denominou como raciocínio preguiçoso. Ele consiste na seguinte ponderação: se o que é para acontecer, acontecerá, independente daquilo que fizeres, então não faça nada. Cícero exemplifica: "se é para te curares, curar-te-ás, independente de chamares o médico ou não, portanto não o chame" (CícERo, 1993). Por conseguinte, reedita-se, no romance, a idêntica relação de causa e efeito manifestada pelo heterônimo, sendo a primeira, a crença na existência no destino, e o respectivo efeito, a mera contemplação.

Ressaltamos o papel preponderante do narrador na relação dialógica retratada, dado que muitas das contestações provêm dele. Ele se homizia no discurso de seu protagonista: "Não digamos, Amanhã farei, porque o mais certo é estarmos cansados amanhã, digamos antes, Depois de amanhã, sempre teremos um dia de intervalo para mudar de opinião e projecto" (p. 64). ${ }^{13} \mathrm{O}$ narrador reitera o emprego da ironia para se contrapor à abulia de Ricardo Reis. E, por vezes, as discordâncias são explícitas: "A vida, curta sendo, não dá para contemplações" (p. 253-4). Ou seja, vislumbra-se o perfil parcial de quem está ao encargo de contar a história. Carvalhal demarca as convicções: "Se Reis se restringe à observação do espectáculo, ao narrador cabe a ação: no relato, a denúncia” (CARvalhal, 1999, p. 123). ${ }^{14}$ Como se, nas entrelinhas do relato das peripécias de Ricardo Reis, o narrador estivesse sina-

13 Teresa C. C. da Silva (1989) salientou haver comunicação deste extrato com um poema de Álvaro de Campos: "O poema 'Adiamento' constitui ainda, a fonte das reflexões de Reis sobre a inércia e desalento" (SiLva, 1989, p. 154).

${ }_{14}$ Sabemos que, para o escritor português, a figura do narrador é indissociável da do autor: "o que digo é que o Autor está no livro todo, que o Autor é todo o livro, mesmo quando o livro não consiga ser todo o autor" (SARAMAGO, 1999, p. 194); "Eu creio que isso que acabamos por denominar 'narrador onisciente' não é outra coisa senão o autor, que dispõe de uma experiência pessoal, assim como uma série de mecanismos que lhe servem para expressar essa voz, e escolhe o adequado de maneira espontânea, sem premeditação" (SARAMAGO, 2010, p. 223). Não debateremos este argumento por não ser o foco substancial desse artigo. 
lizando que tais atitudes não são corretas e adequadas. E o pano de fundo dessas divergências é o estoicismo, isto é, a forma como ele é manifestado na interpretação do protagonista.

Outro conteúdo que está amalgamado ao Ano da morte e à doutrina estoica é a reflexão sobre as circunstâncias políticas. $\mathrm{O}$ romance se passa em pleno regime salazarista cujas características desmentiam o chavão de que Portugal seria um "oásis de paz" (p. 157). Paschkes sustenta em A ditadura salazarista (1985) que as instituições oficiais no período especificado ostentavam apenas uma fachada democrática sob uma essência ditatorial. Outros relatos históricos corroboram:

[Salazar] Tendo garantido a fidelidade do exército, apoiando-se nos 'camisas verdes' e mais ainda na polícia política, a Polícia Internacional e de Defesa do Estado (PIDE), impondo a censura política e moral à imprensa [...], efetuando prisões arbitrárias, deportando, sobretudo para o campo de Tarrafal, em Cabo Verde (Bourdon, 2010, p. 125).

E a tirania do Estado é registrada pelo rumor de que o lugar ao qual Ricardo Reis foi intimado a comparecer era "de má fama" (p. 191), onde ocorriam "interrogatórios a qualquer hora" (p. 191), torturas e castigos, práticas repugnantes que provocavam náuseas, simbolizadas pelo forte cheiro de cebola do agente Victor. ${ }^{15}$ E o narrador, elegendo a perspectiva da população, relata a intimação de forma emblemática: a contrafé recebida por Ricardo Reis é denominada como "um destino que não pode ser lido" (p. 207, grifo nosso). Ou seja, as ações tiranas ofuscamse sob a névoa de uma autoria imprecisa e são assimiladas de uma forma fatalista, como se fossem necessárias ou inevitáveis. Desse modo, em tela é posta a alienação do povo português, cujo protótipo é o protagonista Ricardo Reis, que depunha ser "uma pessoa pacífica" (p. 211) e que não tinha "nada que ver com política" (p. 202). É uma alienação que se funde à mística propagada de que esta nação teria um destino glorioso a cumprir. O narrador ironiza tal crença, pois "chegamos atrasados à construção do quinto império" (p. 358) e sentencia que "somos menos do que terceiras figuras no grande palco do mundo" (p. 288). Lourenço, no ensaio "Portugal como destino", sintetiza:

O sentimento profundo da fragilidade nacional - e o seu reverso, a ideia de que essa fragilidade é um dom, uma dádiva da própria providência e o reino de Portugal espécie de milagre contínuo, expressão da vontade de Deus - é uma constante mitologia, não só histórico-política, mas cultural portuguesa [...]. A sacralização das "origens” faz parte da história dos povos como mitologia. Mas deve ser raro que algum povo tenha tomado tão à letra como Portugal essa inscrição, não apenas mítica, mas filial e já messiânica do seu destino, numa referência, ao mesmo tempo, lendária

15 Teresa C. Cerdeira da Silva (1989) já argumentara que as náuseas sentidas por Ricardo Reis eram o efeito simbólico da brutalidade do Estado. 
e familiar num horizonte transcendente, a do próprio Cristo (LouRENço, 1999, p. 91-2).

Portanto, dissertar sobre o destino em $O$ ano da morte não é meramente uma questão filosófica, mas cultural, religiosa e histórica. E como não é possível desenvolver todos esses âmbitos com a mesma profundidade, elegemos a filosofia estoica por reconhecermos componentes dessa corrente filosófica nas dimensões elencadas. ${ }^{16}$

De outro lado, no mosaico da narrativa, Lídia, camareira do Hotel Bragança, endossa a contraposição do narrador a Ricardo Reis. Ela, cujo irmão era da Marinha e batalhava por ideais revolucionários, não aceitava a conjuntura política como desígnio fatalista. Enquanto o médico apenas reproduzia as notícias dos jornais, aliados do regime vigente, a camareira, com baixo grau de instrução formal, argumentava com perspicácia: "uma coisa eu aprendi, é que as verdades são muitas e estão umas contra as outras” (p. 436). Há uma divergência ideológica entre ambos personagens, pois Lídia não via nos princípios comunistas a pecha criminosa da qual o senso comum se ressentia. O próximo diálogo entre a camareira e o médico comprova a disparidade comportamental:

São os acasos da vida, É o destino, Acreditas no destino, Não há nada mais certo que o destino, A morte ainda é mais certa, A morte também faz parte do destino, e agora vou passar as suas camisas a ferro, lavar a louça, se tiver tempo ainda irei à minha mãe, está sempre a queixar-se que eu não apareço (p. 338).

Reaparece a conexão da morte com o destino, mas o contraponto significativo de Lídia em relação a Ricardo Reis é que a crença na existência do destino não a paralisa, pois ela lista os afazeres a realizar. Em um diálogo com Fernando Pessoa, Ricardo Reis pontua: "Você lembra-me a Lídia, também fala muitas vezes do destino, mas diz outras coisas” (p. 372). Outra discrepância em relação ao protagonista é que a irmã do Daniel Martins, "inteligente, desembaraçada" (p. 364) era uma mulher "difícil de contentar" (p. 221). Ou seja, a camareira instaura uma linha diferencial: nela, a crença no destino não produz a mera contemplação, mas a ação, tanto que ela é descrita como a que tem a "mão castigada de trabalhos" (p. 184), e que é capaz de deitar "abaixo o guarda-louça" (p. 366).

A nova possibilidade interpretativa que apresentaremos compreende a dicotomia entre as visões de mundo de Ricardo Reis e Lídia.

\footnotetext{
16 A filosofia do pórtico permeia o imaginário da nação portuguesa, como demonstra a citação: "Depois do crepúsculo da geração estoicamente épica de 70 e acompanhando-a no seu adeus ao sonho de um país realmente transfigurado e senhor de si mesmo, a paisagem da cultura portuguesa é um deserto de ruínas, um Alcácer Quibir de heroísmo virtual” (Lourenço, 1999, p. 130). E o estoicismo, ademais, se constituiu como um "passageiro clandestino" (DUнот, 2006, p. 215) do cristianismo, dado que o segundo aderiu a algumas das teorias da stoá.
} 


\section{Nova interpretação: tristeza que é já não estar vivo}

Avaliamos como complexa a tarefa de concebermos interpretações inéditas de uma obra que já tenha sido objeto de inúmeros estudos acadêmicos. Afinal, em 2018, completam-se duas décadas que Saramago, o primeiro autor em língua portuguesa, recebeu o prêmio Nobel de literatura. É uma obra que transbordou as margens do rio lusitano e foi traduzida a mais de trinta idiomas, além de ter originado adaptações teatrais e transposições fílmicas.

Para sugerirmos outras possibilidades de leitura, referenciamo-nos na teoria de Calvino sobre os clássicos. Ele os define como "um livro que nunca terminou de dizer aquilo que tinha para dizer" (CALVINO, 2007, p. 11). Estendemos o balizamento de Ítalo para toda a literatura que detém a probabilidade de se tornar clássica, na qual a de Saramago está inserida. Se pudéssemos, portanto, extrair uma frase de $O$ ano da morte que adensa nossa interpretação conjugada com a ética, seria a de que o objetivo do romance é o de fazer "pensar na tristeza que é já não estar vivo" (p. 153). Essa proposição respalda-se no fato de que a substância da linguagem literária é o discurso metafórico. E como é um trabalho que evidencia o diálogo com o pórtico, explanamos o que, da nossa perspectiva, encontra-se na corrente filosófica referida.

Partimos de um dos relatos sobre o nascimento do estoicismo. Zenão de Cítio questionou o oráculo sobre como poderia viver de forma sábia e obteve a resposta de que "teria de igualar-se aos mortos" (Laertius, 1988, p. 181). Alvitre que significa aprender com os antigos, mas que também pode ser decodificado como o conselho de cultivar uma vida exacerbadamente serena e inativa. Octávio Paz, ao comentar a poesia do heterônimo Ricardo Reis, explicita: "O instante é inabitável como o futuro e o estoicismo é um remédio que mata" (PAZ, 1996, p. 219). O escritor mexicano manifesta o que vislumbramos no romance de Saramago: o estoicismo como um remédio que mata. Essa é a divergência substancial de $O$ ano da morte à filosofia de Ricardo Reis. Ou seja, a adesão integral à ética estoica, como exteriorizada pelo personagem, em vez de promover a virtude, renegaria a vida sob diversos matizes.

Nossa crítica apregoa haver um duplo significado para a palavra morte mencionada no título do romance: o literal e o metafórico. Porém, ambos não são incompatíveis. Além da morte relatada nas páginas derradeiras em que o protagonista acompanha Fernando Pessoa ao Cemitério dos Prazeres, trazemos a lume a interpretação de que esta morte apenas desvelou a que estava "mascarada" desde o início. Há, pois, um juízo na narrativa de que vida e morte não são entidades apartadas, mas se consubstanciam dinamicamente. Fernando Pessoa declara que: "Vida e morte é tudo um" (p. 311). O narrador assegura que: "Um morto [...] é o que há de mais concreto neste mundo" (p. 367). Ademais, imagina-se a possibilidade de que as ruas estejam "entupidas de defuntos" (p. 430), bem como Fernando Pessoa confidencia que "os mortos servem-se dos caminhos dos vivos" (p. 89). Ou seja, na 
defesa da premissa de que há o entrelaçamento da vida com a morte, o elemento incomum é a compreensão de que a morte integra o cotidiano dos vivos. $\mathrm{O}$ sentido que sobressai transcende "a morte definidora" (p. 64), e representa uma das "mil mortes" (SHAKESPEARE, 2006, p. 1.558) que o bardo reputou haver na vida. ${ }^{17}$ A obra analisada reitera este prisma, porquanto em um dos diálogos com Ricardo Reis, Fernando Pessoa assegura que a morte é pleonástica, "é mesmo a mais pleonástica de todas as coisas" (p. 250), isto é, ela se repete.

Além disso, o romance não se restringe a uma exposição in abstracto e assenhora-se do exemplo do protagonista. Ricardo Reis, na própria casa, pede que Fernando Pessoa não bata a porta ao sair, ao que este replica: "Fique descansado, não ecoará o som cavo da tampa do sepulcro" (p. 315). O narrador postula o parentesco da morte com o sono e exterioriza os pensamentos do médico ao concluir que "afinal a vida não é muito mais do que estar deitado" (p. 187) e que o mal dele é o sono. E ele também menciona que o protagonista: "Tentou sentir-se morto [...]. Estou vivo, murmurou, depois em voz alta, sonora, Estou vivo, e como não havia ali ninguém que pudesse desmenti-lo, acreditou" (p. 258). O que significa que era uma vida suscetível a ser desmentida, equivalente à morte. O questionamento inevitável é sobre os ingredientes que a deixam nessa condição precária. A resposta também encontramos em $O$ ano da morte: "Que gesto, que palavra, Não sei, morre-se de a não ter dito, morre-se de não o ter feito, é disso que se morre, não de doença” (p. 16o, grifo nosso). O componente fulcral, portanto, é a falta de ação.

Entretanto, sustentar que o protagonista teve uma vida similar à de um morto, não implica ignorar os conflitos inerentes à evolução do personagem. Por vezes, ele duvida de que o verbo "contemplar" constitua-se como uma vereda segura ao substantivo "sabedoria". Entre as subversões à inação está o fato de ele ter exercido a medicina ao substituir um colega cardiologista que teve problemas no coração. Enquanto viajava a Fátima, na expectativa de reencontrar Marcenda, ele diz a palavra: "Parei aí, deixe ver o que é aquilo, eu sou médico" (p. 345); e faz o gesto: "Ricardo Reis desceu, abriu caminho, ajoelhou-se no pó, ao lado do homem, procurou-lhe a artéria, estava morto, Está morto, disse" (p. 345-6). Porém, em que pese tais discrepâncias, o homem sossegado, em última instância, prevalece refugiando-se na máxima: "Sábio é o que se contenta com o espectáculo do mundo, hei-de dizê-lo mil vezes” (p. 461).

Além disso, outras passagens complementam o raciocínio de que as atitudes de Ricardo Reis identificam-se à inação de quem já morreu: "Só estando mortos assistimos" (p. 159, grifo nosso). Ou seja, assistir, isto é, aderir à forma de vida contemplativa, identifica-se à morte. E se acrescenta que são os deuses a fonte de inspiração, conforme o fragmento seguinte: "mas entra-nos no corpo a tentação da mudez, a fascinação da imobilidade, estar como estão os deuses, calados e quietos, assistindo apenas" (p. 51). É um excerto que contém um princípio e as várias atitu-

\footnotetext{
${ }_{17}$ Fragmento da peça Medida por medida: "Na vida, / Escondem-se mil mortes e nós tememos /A morte que nivela tudo" (SHAKESPEARE, 2006, p. 1.558).
} 
des que dele decorrem. O princípio é "estar como estão os deuses", que, como foi aludido, é um dos nucleares objetivos da ética estoica. Os deuses são modelos de perfeição, por este motivo, o ideal é buscar, com perseverança, imitá-los. Daí advém a relevância da atitude contemplativa, "assistindo apenas", conectada à inação, "a fascinação da imobilidade", e à "mudez". Ou seja, reitera-se a conexão intrínseca entre preceitos da ética estoica e a contemplação: "porque os deuses são, resignados, calmos desprendidos, assistindo mortos" (p. 247, grifo nosso).

E o envolvimento amoroso de Ricardo Reis com Marcenda integra idêntico viés. Ela tem a mão esquerda inerte, o que acarreta a sua quase-invalidez. Esta paralisia, cujos motivos permanecem nebulosos, simboliza que ela não é uma mulher de ação. O clínico geral, por sua vez, olha "fascinado a mão paralisada e cega que não sabe aonde há-de ir se a não levarem," (p. 27, grifo nosso). Em segundo lugar, a mão enferma também é denominada como "morte antecipada" (p. 184) e "pássaro morto" (p. 201). Portanto, a atração que Ricardo Reis sente por Marcenda é atração pela inação, que simboliza a morte, coroada pela frase: "A vida é este meu braço esquerdo que está morto e morto ficará” (p. 297). É uma sentença que ratifica o juízo de consubstanciação entre a vida e a morte, agregada à proposição de Ricardo Reis: "Nem um de nós é verdadeiramente vivo nem verdadeiramente morto" (p. 89). A fortuna crítica, a partir de outra passagem do romance, já tangenciou similar interpretação:

[...] mas a pergunta que fazemos é se Ricardo Reis é realmente seduzido por Pessoa ou pela morte. Vimos já que no baile de Carnaval ele corria atrás da morte, mesmo sem saber se se tratava de Pessoa mascarado, preferindo até não o saber (JURSIC, 2012, p. 122).

Portanto, a presente análise traz a lume aspectos que já estavam, de forma latente, em outros estudos da obra do autor português. De acordo com o mesmo artigo citado, a marca de Ricardo Reis é a sua "incapacidade de agir" (JURSIC, 2012, p. 120). Por isso, interpretamos como ambivalente a cena em que Ricardo Reis constata a morte do homem na viagem a Fátima. É o retrato da vã tentativa que ele empreende de subverter a inação, visto que foi uma ação estéril. Ademais, suscitamos que a morte identificada por Ricardo Reis nesse homem estaria sugerindo o reconhecimento da morte que o habitava, descrita pela epígrafe que transcreve Bernardo Soares: "Escolher modos de não agir foi sempre a atenção e o escrúpulo da minha vida" (Pessoa apud SARAMAgo, 2011, p. 7).

\section{Considerações finais}

Um questionamento plausível é se o cotejamento de uma corrente filosófica que nasceu na Grécia antiga com determinada obra literária do século XX é um feito 
imune a anacronismos. Certamente que não, no entanto, o estoicismo detém a peculiaridade de ter se disseminado no decorrer de toda a história das ciências humanas até a contemporaneidade. Além disso, apregoamos que Saramago não visou os estoicos originários, mas a interpretação que é feita dos seus preceitos, como a incorporação feita por Ricardo Reis das diretrizes do pórtico que espelha a da nação portuguesa. Logo, a "morte" do protagonista representa a "morte" da nação, uma vez que ela é denominada como "povo de suicidas" (p. 448) e que tem "sede de martírio" (p. 289). Vislumbra-se que a já exposta conexão do destino à morte não é fortuita, pois, nas palavras de Eduardo Lourenço (1999), o destino arraigou-se no imaginário lusitano. E o romance, cuja sugestão de subtítulo ${ }^{18}$ já foi mencionada, apontou, entre os efeitos nefastos dessa fusão, a letargia: "Alguém transporta ao colo uma criança, que pelo silêncio portuguesa deve ser" (p. 12); "Lisboa é um silêncio que rumoreja" (p. 244); "Se veio para dormir, a terra é boa para isso" (p. 101-2). Contudo, esta percepção terá mais sentido se transcendermos a simbologia à humanidade, dado que os traços realçados na narrativa são universais. Ironicamente, portanto, através de $O$ ano da morte (2011), entrevemos que o sonho "de universalidade" (p. 358), impregnado na história dessa nação, torna-se uma brutal realidade.

A crítica literária que propusemos está intrínseca ao mote do autoconhecimento, que, por sua vez, suscita o viés ético. Quanto a tais conteúdos, existe uma equivalência com outro título deste autor. Se no Ensaio sobre a cegueira (SARAmAgO, 1995), há a denúncia da cegueira do leitor (SeIxo, 1999), em O ano da morte, insinua-se uma paráfrase de Flaubert segundo a qual Ricardo Reis somos nós. E o viés ético se constitui como um apelo à transformação, também similar ao Ensaio. Assim como se pretende que os cegos se tornem capazes de ver, a "morte" do personagem é também uma tentativa de fazê-lo ressurgir. A contrariedade do narrador com Ricardo Reis pode ser decodificada como a intenção de que não nos contentemos em contemplar e que sejamos um dos inúmeros levantados do chão.

\section{Referências}

Bakhtin, Mikhail. Problemas da poética de Dostoiévski. Tradução de Paulo Bezerra. Rio de Janeiro: Forense-Universitária, 1981.

Bourdon, Albert-Alain. História de Portugal. Tradução de Joaquim Soares da Costa. 2. ed. Lisboa: Texto \& Grafia, 2010.

Calvino, Italo. Por que ler os clássicos. Tradução de Nilson Moulin. 2. ed. São Paulo: Companhia das Letras, 2007.

CARvalhal, Tânia Franco. De fantasmas e poetas: o pessoano Saramago. In: BerRINI, Beatriz (Org.). José Saramago: uma homenagem. São Paulo: EDUC, 1999. p. 115-125.

\footnotetext{
18 "Contribuição para o diagnóstico da doença portuguesa" (SARAmAGO, 2010, p. 282).
} 
Castro, Pedro. Todos os nomes da cegueira de Ricardo Reis: estratos estoicos na obra saramaguiana. 2015. Tese (doutorado) - Universidade Federal de Santa Catarina, Florianópolis, 2016.

Cícero, Marco Túlio. Sobre o destino. Tradução e notas de José R. Seabra Filho. São Paulo: Nova Alexandria, 1993.

Duнot, Jean-Joël. Epicteto e a sabedoria estoica. Tradução de Marcelo Perine. São Paulo: Loyola, 2006.

Hirschberger, Johannes. História da filosofia na antiguidade. Tradução e prefácio de Alexandre Correia. São Paulo: Herder, 1965.

Jursic, Bárbara. O fantasma de Ricardo Reis segundo Saramago. Revista Colóquio Letras, Lisboa, n. 181, p. 117-124, set./dez. 2012.

Kristeva, Julia. Introdução à semanálise. Tradução de Lúcia H. França Ferraz. São Paulo: Perspectiva, 1974 .

LAertius, Diógenes. Vidas e doutrinas dos filósofos ilustres. Tradução do grego, introdução e notas de Mário Gama Cury. Brasília: Editora da UnB, 1988.

Lourenço, Eduardo. Portugal como destino. In: Lourenço, Eduardo. Mitologia da saudade seguido de Portugal como destino. São Paulo: Companhia das Letras, 1999. p. $87-154$.

Marinho, Maria Celina Novaes. Transmissão do discurso alheio e formas de dialogismo em Vidas Secas, de Graciliano Ramos. In: BraIt, Beth (Org.). Bakhtin, dialogismo e construção do sentido. Campinas: Editora da Unicamp, 1997. p. 249-26o

PaIs, Amélia Pinto. Para compreender Fernando Pessoa: uma aproximação a Fernando Pessoa e seus heterônimos. São Paulo: Claro Enigma, 2012.

Paschkes, Maria Luisa de Almeida. A ditadura salazarista. São Paulo: Brasiliense, 1985 .

PAz, Octávio. O desconhecido de si mesmo - Fernando Pessoa. In: PAz, Octávio. Signos em rotação. Tradução de Sebastião Uchôa Leite. Organização e revisão de Celso Lafer e Haroldo de Campos. 3. ed. São Paulo: Perspectiva, 1996. p. 201-220.

PessoA, Fernando. Obras em prosa. Organização, apresentação e notas de Cleonice Berardinelli. Rio de Janeiro: Nova Aguilar, 1998.

PessoA, Fernando. Poesia completa de Ricardo Reis. Organização de Manuela Parreira da Silva. São Paulo: Companhia das Letras, 2007.

Reale, Giovanni. História da filosofia antiga. Tradução de Marcelo Perine e Henrique C. de Lima Vaz. São Paulo: Loyola, 1994. v. 3.

Rist, John M. La filosofia estoica. Barcelona: Crítica, 1995. 
Saramago, José. As palavras de Saramago: catálogo de reflexões pessoais, literárias e políticas. Seleção e organização de Fernando Gómez Aguilera. São Paulo: Companhia das Letras, 2010.

SARAmago, José. Cadernos de Lanzarote II. São Paulo: Companhia das Letras, 1999.

Saramago, José. Ensaio sobre a cegueira. São Paulo: Companhia das Letras, 1995.

Saramago, José. O ano da morte de Ricardo Reis. São Paulo: Companhia da Letras, 2011. (Coleção Prêmio Nobel)

Schofield, Malcolm. Ética estoica. In: Wood, Brad (Org.). Os estoicos. Tradução de Paulo F. T. Ferreira e Raul Fiker. São Paulo: Odysseus, 2006. p. 259-284.

Sedley, David. Os deuses e os homens. Tradução do inglês por Christelle Veillard. In: Gourinat, Jean-Baptiste; BARnes, Jonathan. Ler os estoicos. Tradução de Paula S. R. C. Silva. São Paulo: Loyola, 2013. p. 95-116.

Seixo, Maria Alzira. Lugares da ficção em fosé Saramago: o essencial e outros ensaios. Lisboa: Imprensa Nacional, 1999.

SÊNecA. Lúcio Aneu. Cartas a Lucílio. Tradução, prefácio e notas de J. A. Segurado e Campos. 2. ed. Lisboa: Fundação Calouste Gulbenkian, 2004.

SÊnecA. Lúcio Aneu. Da tranquilidade da alma. In: SÊneCA. Lúcio Aneu. Antologia de textos. Traduções e notas de Agostinho da Silva et al. 2. ed. São Paulo: Abril Cultural, 1980.

SÊNECA. Lúcio Aneu. Tratados filosóficos. Tradução de Pedro Fernández de Navarrete. Buenos Aires: El Ateneo, 1952.

Severino, Emanuele. A filosofia antiga. Tradução de José Eduardo Rodil. Lisboa: Edições 70, 1984.

Shakespeare. William. Medida por medida. In: Shakespeare. William. Teatro completo: tragédias e comédias sombrias. Tradução de Bárbara Heliodora. Rio de Janeiro: Nova Aguilar, 2006. p. 1503-1622.

Silva, Augusto Santos. O escritor exorta os seus concidadãos (ou o discurso político da ficção de Saramago). In: Margato, Izabel; Gomes, Renato Cordeiro (Org.). Literatura/Política/Cultura: (1994-2004). Belo Horizonte: Editora da UFMG, 2005. p. 13-56.

Silva, Teresa Cristina Cerdeira. José Saramago - Entre a história e a ficção: uma saga de portugueses. Lisboa: Dom Quixote, 1989.

Ullmann, Reinholdo Aloysio. Estoicismo romano: Sêneca, Epicteto, Marco Aurélio. Porto Alegre: EdiPUCRS, 1996.

Voltaire. Cândido ou o optimismo. In: Voltaire. Contos e novelas. Tradução de Mário Quintana. São Paulo: Globo, 2005. 
Recebido em 7 de agosto de 2017.

Revisão em 14 de dezembro de 2017.

Aprovado em 19 de janeiro de 2018.

\section{Resumo/Abstract/Resumen}

\section{O ano da vida e da morte do estoico Ricardo Reis}

\section{Pedro Nunes Castro \\ Rosane Maria Cardoso}

Este artigo segue a esteira de outros estudos que evidenciaram a interação profícua da obra de José Saramago com a filosofia. Fixando-nos em $O$ ano da morte de Ricardo Reis (1984) pretendemos demonstrar que, neste romance, o estoicismo é um componente intertextual determinante. Aprofundamos o já bastante explorado diálogo com Ricardo Reis, trazendo a lume os seus traços estoicos, porquanto preconizamos que o estoicismo do heterônimo de Fernando Pessoa é herdado pelo protagonista do título referido. E para relevar os fios da filosofia estoica neste tecido narrativo, referenciamo-nos em Kristeva (1974) e Mikhail Bakhtin (1981), que asseveram a onipresença da intertextualidade e do dialogismo na linguagem literária. Entendemos que há uma relação dialógica entre o romance de Saramago e a corrente filosófica e que destacá-la renderá novas possibilidades hermenêuticas.

Palavras-chave: José Saramago, Ricardo Reis, estoicismo, intertextualidade, dialogismo.

\section{The year of the life and the death of the stoic Ricardo Reis}

\section{Pedro Nunes Castro \\ Rosane Maria Cardoso}

This paper follows the footsteps of other studies which have showed the successful interaction between José Saramago's work and Philosophy. Focusing on The Year of the Death of Ricardo Reis (1984), we intend to show that, in this novel, the stoicism is a decisive intertextual component. The well-explored dialogue with Ricardo Reis was deepened, bringing to light his stoic characteristics, since we believe that the stoicism of the heteronym of Fernando Pessoa is inherited by the main character of the aforementioned title. Thus, in order to reveal the threads of the stoic Philosophy in this narrative, Kristeva (1974) and Mikhail Bakhtin (1981) were used as reference, since both assert the omnipresence of intertextuality and dialogism in the literary language. We believe that there is a dialogic relation between Saramago's novel and the philosophical movement, and highlighting it will bring new hermeneutic possibilities. 
Keywords: José Saramago, Ricardo Reis, stoicism, intertextuality, dialogism.

\section{El año de la vida y de la muerte del estoico Ricardo Reis}

\section{Pedro Nunes Castro}

\section{Rosane Maria Cardoso}

Este artículo sigue la línea de otros estudios que han evidenciado la interacción proficua de la obra de José Saramago con la filosofía. Fijándonos en El año de la muerte de Ricardo Reis (1984) pretendemos demostrar que en esta novela el estoicismo es un componente intertextual determinante. Profundizamos en el ya bastante explorado diálogo con Ricardo Reis, esclareciendo sus rasgos estoicos, puesto que preconizamos que el estoicismo del heterónimo de Fernando Pessoa es heredado por el protagonista de dicho título. Para relevar los hilos de la filosofía estoica en este tejido narrativo, nos referenciamos en Kristeva (1974) y en Mikhail Bakhtin (1981), que aseveran la omnipresencia de la intertextualidad y del dialogismo en el lenguaje literario. Entendemos que hay una relación dialógica entre la novela de Saramago y la corriente filosófica, y que resaltarla abrirá nuevas posibilidades hermenéuticas.

Palabras clave: José Saramago, Ricardo Reis, estoicismo, intertextualidad, dialogismo. 